\title{
A Dream House Model for Increasing Micro Small Enterprise Performance
}

\author{
Ni Kadek Sinarwati ${ }^{1, *}$ Luh Gede Kusuma Dewi ${ }^{1}$ I Nyoman Putra Yasa ${ }^{1}$ I Made Pradana \\ Adi Putra ${ }^{1}$ \\ ${ }^{1}$ Department of Economics and Accounting, Universitas Pendidikan Ganesha, Singaraja, Indonesia \\ *Corresponding author. Email: nikadeksinarwati@undiksha.ac.id
}

\begin{abstract}
The objective of this study is to build a model for improving the performance of MSEs through optimizing the role of BUMDes. The data collected was primary data consisting of the causes of the low performance of MSEs, the idea of optimizing the role of BUMDes in improving the performance of MSEs. Data were collected by interview, in-depth interview and Focus Group Discussion (FGD) methods. The data analysis technique begins by reviewing the causes of the low performance of MSEs through Fishbone analysis, followed by a SWOT analysis to know opportunities and threats to increase the role of BUMDes and ending by building a model for improving MSE performance through optimizing the role of BUMDes using the Dream House Model.The results show that the model for improving the performance of MSEs through optimizing the role of BUMDes, which was named the Dream House Model, requires that MSEs set a dream to experience an increase in performance which is set within three years. The main pillar of achieving this dream was that MSEs should revitalize and collaborate. A strong foundation in achieving this dream was that MSEs must consistently implement strategies. Optimization of the role of BUMDes was carried out in collaboration with MSEs and BUMDes which acts as a forum for business activities for MSEs actors in rural areas. The managerial implication of the research was that MSEs actors should revitalize/improve in the fields of human resources, production, marketing and administration. The support of BUMDes, local governments and Universities was needed to help MSEs achieve their dreams.
\end{abstract}

Keywords: BUMDes, MSEs, Performance.

\section{INTRODUCTION}

The existence of MSEs in the Province of Bali as one of the supporters of the tourism sector is favored in increasing local revenue. Data on investment value, production value, number of workers, number of business units and average age of MSE in each Regency/City in Bali Province are presented in Table 1.

The data in Table 1 shows that the lowest production and employment values were in Karangasem Regency, this shows that the performance of MSEs in Karangasem Regency is the lowest compared to eight other regencies/cities. The problem of the lowest performance of SMEs in Karangasem Regency compared to other regencies/cities is important to analyze and find a solution, considering the problem of inequality is one of the issues studied in the sustainable development goals (SDGs).

The main problem analyzed in this research is the low performance of MSEs in Karangasem Regency. Low MSE performance indicator is low production value. The cause of the low production value is due to lack of capital. This is something that should not happen considering that in Karangasem Regency there are many microfinance institutions, one of which is Village Owned Enterprises (BUMDes) which offer loans with low interest rates and easy terms. Ideally BUMDes can play an optimal role in improving the performance of MSEs, but in reality so far BUMDes in Karangasem Regency have not played an optimal role in improving MSE performance. [1] found that BUMDes played a positive but not significant role on the performance of craftsmen in Karangasem Regency. 
Table 1.Data of MSEs in Bali Province

\begin{tabular}{|c|c|c|c|c|c|c|}
\hline No & Regency/City & $\begin{array}{c}\text { Investment } \\
\text { Value } \\
\text { (Rp) }\end{array}$ & $\begin{array}{l}\text { Production Value } \\
\qquad(\mathrm{Rp})\end{array}$ & $\begin{array}{c}\text { Number of } \\
\text { Labour(person) }\end{array}$ & $\begin{array}{c}\text { Number of business } \\
\text { unit }\end{array}$ & $\begin{array}{l}\text { Average } \\
\text { age(year) }\end{array}$ \\
\hline 1 & Jembrana & 73.933 .433 & 429.536 .074 & 8.712 & 1.750 & 18 \\
\hline 2 & Tabanan & 542.345 .198 & 567.236 .330 & 7.606 & 878 & 2 \\
\hline 3 & Denpasar & 283.412 .455 & 1.418 .492 .548 & 30.974 & 4.074 & - \\
\hline 4 & Badung & 72.444 .562 & 1.246 .268 .358 & 14.943 & 1.230 & 23 \\
\hline 5 & Gianyar & 2.989.867.354 & 4.841 .849 .850 & 15.058 & 943 & 15 \\
\hline 6 & Bangli & 24.371 .071 & 363.330 .010 & 11.741 & 4.167 & 14 \\
\hline 7 & Karangasem & 25.737 .579 & 32.213 .224 & 4.210 & 512 & 16 \\
\hline 8 & Klungkung & 29.274 .729 & 92.890 .481 & 4.617 & 461 & 16 \\
\hline 9 & Buleleng & 22.012.121 & 183.092.572 & 6.220 & 977 & 15 \\
\hline
\end{tabular}

Source:Bali Province Industry and Trade Office

The presence of BUMDes should help MSEs in the village both with capital assistance and marketing assistance. In general, this study aims to improve the village economy through optimizing the role of BUMDes in improving the performance of MSEs. The development of a performance improvement model through optimizing the role of BUMDes is a solution to improve the performance of MSEs towards improving the economy in the village. The purpose of this study is to build a model for improving the performance of MSEs through optimizing the role of BUMDes.

\section{LITERATUR REVIEW}

Performance can be an individual performance or group work of personnel. The appearance of the work is not limited to personnel holding functional and structural positions, but also to the entire line of personnel within the organization. The description of performance involves three important components, namely: objectives, measures and assessments. Determining the goals of each organizational unit is a strategy to improve performance. This goal will give direction and influence how the work behavior that the organization expects of each personnel should be. However, setting goals alone is not enough, because it takes a measure of whether someone has achieved the expected performance.

States that the factors that affect performance are abbreviated as 'ACHIEVE' which means Ability (ability that can be developed), Capacity (defined/limited ability), Help (assistance for the realization of performance, Incentives (material and non-material incentives), Environment (employee work environment), Validity (guidelines / instructions and job descriptions) and
- The data is not available

Evaluation (there is feedback on work results) [2]. Designed a SWOT analysis-based MSE management model to produce a strategy to provide training to all aspects, considering the lack of knowledge possessed by MSEs, and helping to introduce information technology as an information technology-based marketing approach [3]. Designed a financial inclusion model for rural-based MSMEs to produce a financial inclusion model for Batik MSEs in Klaten Regency, namely the inclusion of financial institutions in in terms of capital, namely in the form of low interest loans which is then carried out with assistance by financial institutions [4]. Conducted research on determining business sustainability strategies in culinary MSEs using the SWOT AHP method to produce a strategy consisting of opening local branches and conducting partnerships [5]. Conducted a study on the Strategic Management Approach Study Model in Improving the MSEs Sector in the City of Bandung found that the development of the MSEs in the city of Bandung can be carried out with strategic development followed by a SWOT analysis [6].

Research on BUMDes conducted by [7] with the research "Village-Owned Enterprises as an Alternative for Village Income", concluded that a commitment is needed to build BUMDes in order to increase the competitiveness of the village economy. Examined the institutionalization of BUMDes as a driver of village economic potential in poverty alleviation efforts in Donggala Regency, resulting in the characteristics of BUMDes as an institution in empowering the community in the form of a legal entity, being the center of village community economic activities, becoming a source of village income, and provide services to rural communities [8]. 


\section{METHOD}

This study uses a Research and Development approach which aims to develop a model for improving the performance of MSEs through optimizing the role of BUMDes. The data collected is the cause of the low performance of MSEs and opportunities for collaboration between MSEs and BUMDes. The type of data used is primary data, namely the performance of MSEs and the role of BUMDes is not yet optimal. Data collection methods were interviews, in-depth interviews and Focus Group Discussions (FGD) which were attended by MSES experts, BUMDes experts, BUMDes managers and MSES actors in Karangasem Regency. Research respondents were determined by purposive sampling technique with the criteria for MSES and BUMDes actors with the highest capital in each sub-district.

The data analysis technique used was the presentation of the root of the problem and the cause of the problem by using fish bone analysis. The next step is to analyze using SWOT analysis to find out the threats and opportunities for MSME-BUMDes collaboration. The final step is to develop a model using the Dream House Model developed by Horovtz and Ohlsson-Corboz (2007) in [9].

The results of in-depth interviews and Focus Discussions (FGD) show some of the problems faced by MSEs, especially in rural areas in Karangasem Regency, if presented according to fish bone analysis presented in Figure1.
After analyzing the opportunities and threats of improving the performance of MSEs by optimizing the role of BUMDes which is carried out through the collaboration of MSES-BUMDes, the next step is to develop a model for improving the performance of MSEs using the Dream House Model developed by OhlssonCorboz (2007) in [9]. This model sets out the vision/dream that MSEs want to achieve in a certain time in this study within three years. The dream to be realized is to improve performance with indicators of increasing profits and increasing employment. The two main pillars of achieving dreams are revitalization and collaboration. A solid foundation for achieving dreams is consistently executing strategy. The form of the Dream House model The MSEs Performance Improvement Model through Optimizing the Role of BUMDes is presented in Figure 2.

\section{RESULTS \& DISCUSSION}

Performance improvement indicators that are set to be achieved within three years are increased profits and increased employment. The two main pillars to realize this dream are MSEs actors revitalizing and collaborating. The intended revitalization is that MSEs make improvements in their business management by making improvements in the fields of production, marketing and administration/finance.

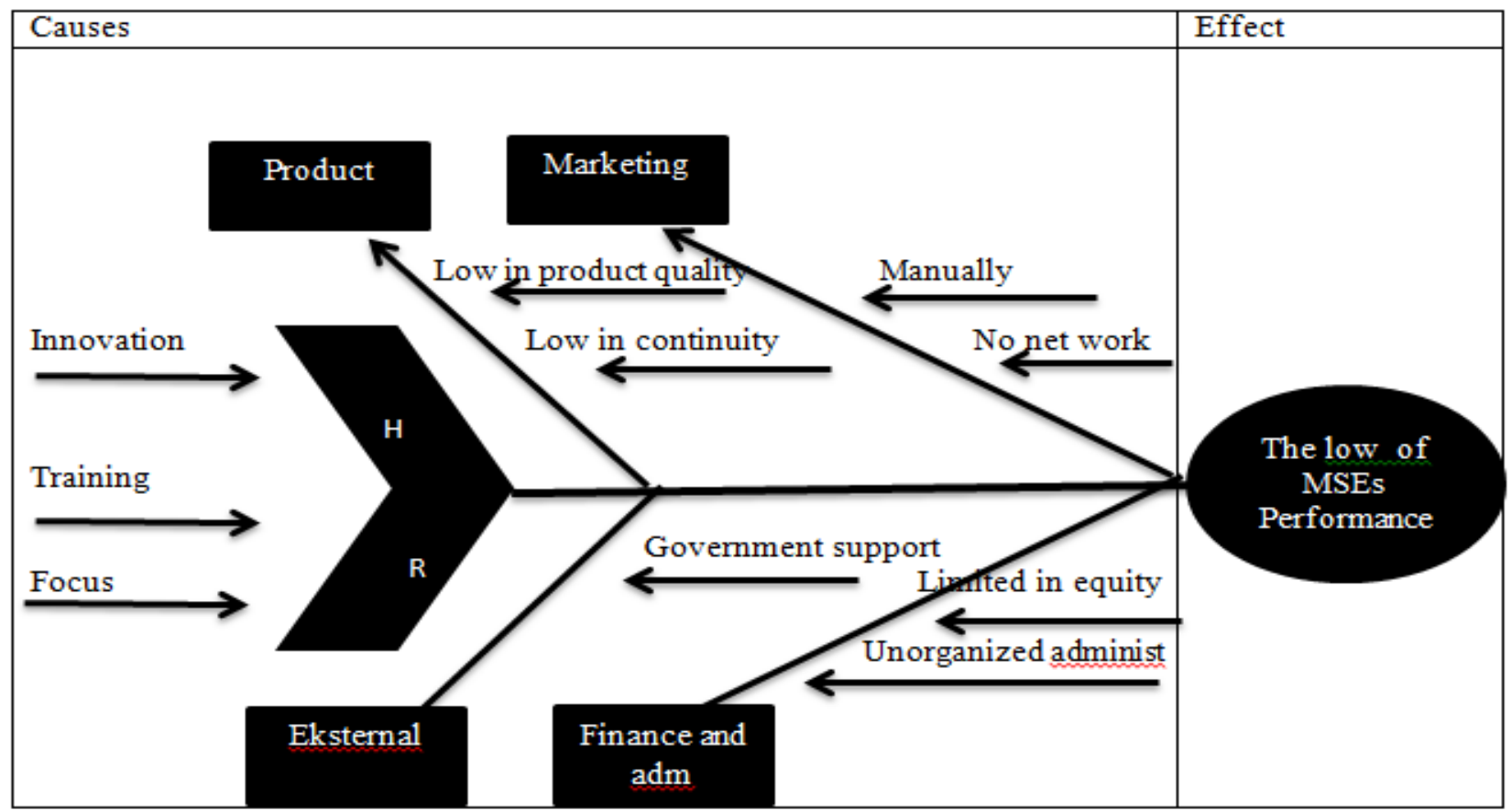

Figure1. Causes of low MSEs Performance 


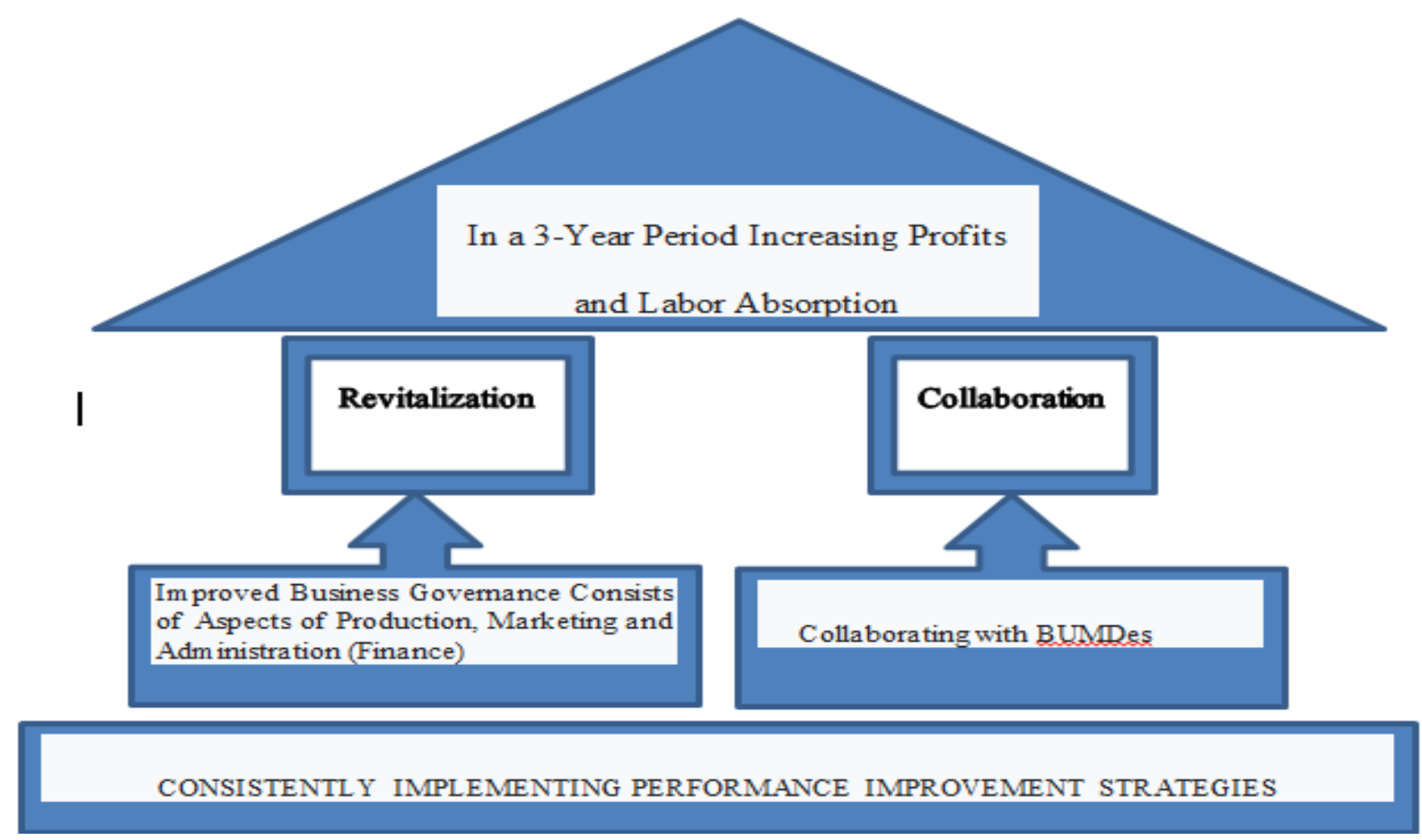

Figure 2. The Dream House Model

Improvements in the production sector are carried out by increasing product design innovation, maintaining product continuity and setting product standards, which include raw material standards and production process standards so that product quality increases and has high competitiveness [9]. Revitalization in the marketing field can be done by selling online, finding markets independently without depending on one distributor, forming a network to expand the market. Revitalization in the field of administration and finance can be done by routinely recording business transactions, compiling computerized financial reports and separating business assets from personal assets. A clear and neat business administration is one of the requirements for obtaining a loan or credit from a financial institution. The preparation of business financial reports on a regular basis is also useful in providing information on operating results, cash flows and the development of invested capital. Business revitalization can be done by participating in training or workshops to improve the competence of Human Resources.

The second main pillar that MSEs can do to achieve their dreams is to collaborate with Village-Owned Enterprises (BUMDes). Optimization of the role of BUMDes in improving performance is carried out by the presence of BUMDes as an economic forum for MSES products in rural areas. BUMDes, which is a village social entrepreneurship institution, does not exist as a competitor and should not be a predator of village economic enterprises. The presence of BUMDes in the chain of activities of MSES actors in the village becomes a forum for the village economy, for example, BUMDes acts as a provider of raw materials for handicraft products, supports funds / lenders and as distributor agents to increase sales of MSEs products.

\section{CONCLUSION}

The results of interviews with micro-enterprises and the results of Focus Group Discussions show that the causes of the low performance of MSEs, especially in rural areas, are Human Resources/HR problems, product and production problems, marketing problems, and administrative and financial problems. external cause was government support. The model for improving the performance of MSEs through optimizing the role of BUMDes was built by analyzing the causes of the low performance of MSEs using fish bone analysis, conducting a SWOT analysis to find out the opportunities and challenges of MSEs-BUMDes collaboration in order to improve the performance of MSEs through optimizing the role of BUMDes. The next step is to build a model using the Dream House Model. The final step is to determine the Main Performance Indicators and MSEs Performance Achievement Targets. Suggestions put forward in order 
to achieve the general objectives of the research are aimed at MSEs actors consistently carrying out revitalization and collaboration to achieve the vision of improving performance. BUMDes is a consistent partner for MSEs and a forum for products produced by MSEs, especially in rural areas. The managerial implication of this research is that the low performance of MSEs is mostly caused by internal factors, namely from within MSEs, namely HR, production, marketing and administration issues. The support of BUMDes, the government and Universities were expected to help MSEs achieve their dreams.

\section{ACKNOWLEDGMENTS}

The author would like to thank the Institute for Research and Community Service (LP2M) Universitas Pendidikan Ganesha, because this article is a summary of research funded by LP2M Universitas Pendidikan Ganesha.

\section{REFERENCES}

[1] N. K. Sinarwati, A. A. I. N. Marhaeni, I. M. S. Utama, and M. K. S. Budhi, "Does Entrepreneurship Supply Chain Management Mediate the Effect of VOE Resources and Social Capital to Performance of Craftsmen?," Int. J. Supply Chain Manag., vol. 9, no. 5, pp. 166951701, 2020.

[2] S. Notoatmodjo, Kesehatan Masyarakat "Seni dan Ilmu. ” Jakarta: Rineka Cipta, 2009.

[3] L. Bismala and S. Handayani, "Model Manajemen MSESM Berbasis Analisis SWOT," Naskah Lengkap Semin. Nas. PB3I ITM, 2014.

[4] D. Irmawati, Setyani, Damelia and D. W. Puspita, "Model Inklusi Keuangan Pada MSESM Berbasis Pedesaan," J. Econ. Policy, 2013, [Online]. Available: http://journal.unnes.ac.id/nju/index.php/jejak.

[5] S. Setiyadi, K. Amar, and T. Aji, "Penentuan Strategi Sustainability Usaha Pada UKM Kuliner Dengan Menggunakan Metode SWOT- AHP," $J$. Ilm. Tek. Ind., vol. 10, no. 2, 2011.

[6] S. Machmud and I. Sidharta, "Model Kajian Pendekatan Manajemen Strategik Dalam Peningkatan Sektor MSESM di Kota Bandung," J. Comput. Bisnis, vol. 7, no. 1, pp. 56-66, 2013.

[7] I. S. Widodo, "Badan Usaha Milik Desa Sebagai Salah Satu Alternatif Sumber Pendapatan Desa Berdasarkan Undang-Undang No. 6 Tahun 2014 Tentang Desa," J. Panor. Huk., vol. 1, no. 1, 2016.
[8] H. M. Sayuti, "Pelembagaan Badan Usaha Milik Desa (BUMDs) Sebagai Penggerak Potensi Ekonomi Desa Dalam Upaya Pengentasa Kemiskinan Di Kabupaten Donggala," J. Acad. Fisip Untad, vol. 3, no. 2, 2011.

[9] M. Tahwin and N. Kusumaningsih, "MODEL PENINGKATAN KINERJA USAHA KECIL DAN MENENGAH MENGGUNAKAN THE DREAM HOUSE MODEL (Studi Kasus Industri Batik Tulis Lasem Kabupaten Rembang)," Bul. Bisnis Manaj., vol. 4, no. 1, 2018, [Online]. Available: http://journal.stieyppi.ac.id/index.php/BBM/article/view/152. 